\title{
Xylanase production by Aspergillus fumigatus UR01 by solid state fermentation of rice straw
}

\begin{abstract}
Suwattana Singhajutha, Eakaphun Bangyeekhun, Urarux Romruen* Department of Microbiology, Faculty of Science, Silpakorn University, Nakhon Pathom, 73000 Thailand

Received:

July 06, 2019

Accepted:

June 18, 2020

Published:

October 31, 2020

Abstract

Sugar generation is important for many industries, such as livestock feed and bioethanol production. Rice straw is an agricultural waste that serves as a good source of sugar. In this study, a xylanase-producing fungus was isolated form compost pile and identified as Aspergillus fumigatus based on the internal transcribing spacer sequence. Xylanase produced by this fungus was characterised. The optimal conditions for fungal xylanase activity were $55^{\circ} \mathrm{C}$ and $\mathrm{pH}$ 5.0. Enzyme activity declined to $45.26 \%$ following incubation at $50^{\circ} \mathrm{C}$ for 2 days. Rice straw was more suitable for xylanase production than other substrates. The filtrate of A. fumigatus grown on rice straw as a substrate was added to rice straw, and reducing sugar production was determined. The maximum reducing sugar production was achieved with incubation at $30^{\circ} \mathrm{C}$ for $18 \mathrm{~h}$. Xylanase produced by A. fumigatus can be used for rice straw pre-treatment to improve the nutrient content of livestock feed and increase bioethanol production.
\end{abstract}

Corresponding author email: urarux12@gmail.com
Keywords: Xylanase, Rice straw, Agricultural waste, Sugar

\section{How to cite this:}

Singhajutha S, Bangyeekhun E and Romruen U, 2020. Xylanase production by Aspergillus fumigatus UR01 by solid state fermentation of rice straw. Asian J. Agric. Biol. 8(4): 422-427. DOI: https://doi.org/10.35495/ajab.2019.06.273

This is an Open Access article distributed under the terms of the Creative Commons Attribution 3.0 License. (https://creativecommons.org/licenses/by/3.0), which permits unrestricted use, distribution, and reproduction in any medium, provided the original work is properly cited.

\section{Introduction}

Rice straw is one of the major agricultural wastes produced in rice-producing Asian countries such as Bangladesh, China, India, Indonesia, Vietnam and Thailand. In 2013, 12.15 million tonnes of rice straw was produced in Thailand (Sheikh et al., 2018). Rice straw primarily contains ash $(7.45 \%)$, lignin (18.12\%), hemicellulose $(28.45 \%)$ and cellulose (34.12\%) (Sindhu et al., 2012). Following fermentation, rice straw can serve as a source of sugar and can thus be used for livestock feed and bioethanol production. During biomass conversion of rice straw to bioethanol, an important step is the production of fermentable sugars via hemicellulose hydrolysis. However, this process is slow due to the crystalline structure of the hemicellulose. Currently, enzymes produced by fungi and bacteria are used to enhance the efficiency of sugar production (Choudhary et al., 2014; Makhuvelea et al., 2017). As livestock feed, the digestibility of rice straw is rather low. Rice straw can be pretreated to overcome this problem. Several chemical, physical and biological pre-treatment methods have been reported recently (Khan et al., 2015). Chemical pre-treatment is performed using urea, ammonia or alkali (sodium hydroxide or calcium hydroxide), and physical pre-treatment involves chopping, streaming or grinding; moreover, both pre- 
treatments are often used together (Jayanegara et al., 2017; Sheikh et al., 2018). For biological pretreatment, fibre-degrading enzymes produced by fungi are used. This biological pre-treatment method is preferred due to its environmental sustainability and safety (Sheikh et al., 2018). However, the commercial enzymes used to generate sugar for livestock feed and bioethanol production are expensive (Thammiah et al., 2017).

Xylanases are a class of enzymes used for sugar production from straw. These enzymes collaborate to degrade hemicellulose (a polymer of xylan and other C5 sugars) in rice straw (Sindhu et al., 2012). Xylanases include $\beta$-xylosidase (EC 3.2.1.37), endoxylanase (EC 3.2.1.8) and other enzymes with side-branch splitting (Maheshwari et al., 2000). Filamentous fungi are an important source of xylanase, and these can readily produce enzymes via solid state fermentation (Ang et al., 2013).

In this study, xylanase-producing fungi were isolated from compost pile and genetically identified. In addition, the optimal conditions for fungal xylanase activity were characterised. Various agricultural wastes were tested as suitable substrates for fungal cultivation. Finally, the crude enzyme was used to pretreat rice straw for sugar production.

\section{Material and Methods}

\section{Fungal isolation}

Fungi were isolated from compost pile by culturing on potato dextrose agar at $45^{\circ} \mathrm{C}$ for 5 days. Fungal morphology was examined under a light microscope.

\section{Spore suspension}

The spore suspension was prepared using $0.1 \%(\mathrm{v} / \mathrm{v})$ Tween 80, and the spore concentration was measured using a hemocytometer. The suspension was diluted to $1 \times 10^{5}$ spores $/ \mathrm{mL}$ for inoculation.

\section{Xylanase assay}

Fungal mycelia were cultured in a minimal medium supplemented with $2 \%(\mathrm{w} / \mathrm{v})$ xylan from birch wood as the sole carbon source. The fungal culture was filtered through a filter cloth, and the filtrate was diluted to appropriate concentration. Then, $0.5 \mathrm{~mL}$ the diluted filtrate was added to $0.5 \mathrm{~mL} 1 \%(\mathrm{w} / \mathrm{v})$ xylan from birch wood in $0.05 \mathrm{M}$ sodium acetate buffer $(\mathrm{pH}$ 5.0). The cultures were incubated at $55^{\circ} \mathrm{C}$ for $1 \mathrm{~h}$. Following incubation, dinitrosalicylic acid $(1 \mathrm{~mL})$ was added. The cultures were boiled for $10 \mathrm{~min}$ and chilled on ice for $3 \mathrm{~min}$. Absorbance was measured using a spectrophotometer at $540 \mathrm{~nm}$ (Miller, 1972). The amount of enzyme required to release $1 \mu \mathrm{M}$ of reducing sugar per minute under the assay conditions was measured.

\section{Fungal DNA extraction and identification}

Fungal mycelia were filtered from broth cultures and washed three times with deionised water. The mycelia were ground to a fine powder in liquid nitrogen using mortar and pestle. Genomic DNA was extracted using the phenol-chloroform method, as described by Chukeatirote et al., 2012. Dried DNA pellet was resuspended in $50 \mu \mathrm{L}$ TE buffer. The internal transcribing spacer (ITS) region was amplified using the primers ITS1 (5'TCCGTAGGTGAACCTGCGG-3') and ITS4 (5'TCCTCCGC-TTATTGATATGC-3') and sequenced. A phylogenetic tree was constructed using the neighbour-joining method (MEGA4 software).

\section{Optimal conditions for xylanase production}

Fungal spores were cultured in a minimal medium supplemented with $2 \%(\mathrm{w} / \mathrm{v})$ xylan and incubated at $45^{\circ} \mathrm{C}$ for 10 days. Xylanase activity in the culture filtrates was assessed at various conditions: temperature range $30^{\circ} \mathrm{C}-75^{\circ} \mathrm{C}$ and $\mathrm{pH}$ range $3-6$.

\section{Xylanase stability}

The culture filtrates were incubated at $50^{\circ} \mathrm{C}, 60^{\circ} \mathrm{C}$ or $70^{\circ} \mathrm{C}$. Xylanase activity was measured every 2 days.

\section{Solid state fermentation}

Various agricultural wastes, including husk, rice bran, nutshell, rice straw, sawdust, coconut residue, bagasse, corn husk, coir and corn cob, were tested as substrates for solid state fermentation. The substrates were dried and chopped into small pieces $(\sim 0.5-2$ inches). Each substrate (10 g) was mixed with a medium (15 mL) containing $10 \mathrm{~g} \mathrm{NaNO}_{3}, 3.3 \mathrm{~g}$ $\mathrm{K}_{2} \mathrm{HPO}_{4}, 1.6 \mathrm{~g} \mathrm{MgSO}_{4}, 0.0003 \mathrm{~g} \mathrm{FeSO}_{4}, 0.4 \mathrm{~g} \mathrm{KCl}$, $1.6 \mathrm{~g}$ peptone, $1.6 \mathrm{~g}$ yeast extract per litre of the medium (Thiagarajan et al., 2005). The spore suspension $\left(1 \times 10^{5}\right.$ spores $\left./ \mathrm{mL}\right)$ was inoculated, and the cultures were incubated at $45^{\circ} \mathrm{C}$ for 7 days. Following incubation, $0.05 \mathrm{M}$ sodium acetate buffer (pH 5.0) was added, and the cultures were incubated for additional $1 \mathrm{~h}$ on a shaker at $180 \mathrm{rpm}$ and $45^{\circ} \mathrm{C}$. The culture was filtered, and xylanase activity in the 
filtrate was measured.

\section{Rice straw degradation}

Rice straw was dried and chopped into small pieces ( 0.5-2 inches). Crude enzyme $(160 \mathrm{~mL})$ was added to $10 \mathrm{~g}$ of rice straw. Flasks were incubated at room temperature $\left(30^{\circ} \mathrm{C}\right)$ for $3,6,12,18,24$ or $30 \mathrm{~h}$. A filtrate without the spores was used as a negative control. After incubation, sugar production was determined using the DNSA method.

\section{Results and Discussion}

\section{Isolation and identification of xylanase-producing fungi}

A total of 10 different fungi were isolated from compost piles. The isolates were cultured in a minimal medium containing $2 \%(\mathrm{w} / \mathrm{v})$ xylan, and xylanase activity was determined. Xylanase activity was detected in the fungal isolates UR01, UR02, UR03 and UR07 but not in UR04, UR05, UR06, UR08, UR09 and UR10. UR01 showed the highest activity and was thus selected for further experiments (Figure 1).

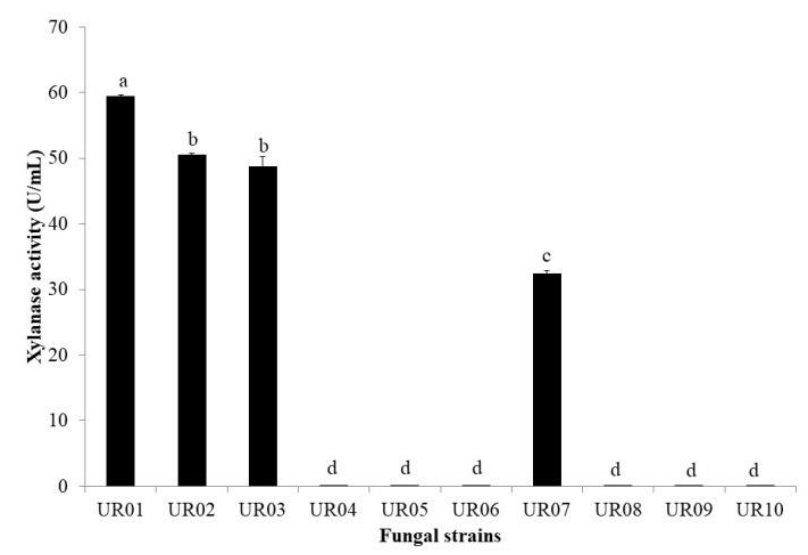

Figure-1. Xylanase activity of fungi isolated from compost pile.

Genomic DNA of UR01 was extracted using the phenol-chloroform method. The ITS region was amplified, sequenced and compared with that of other fungi in the National Center for Biotechnology Information database. The phylogenetic tree indicated that the ITS region of UR01 shared $100 \%$ similarity with the ITS region of Aspergillus fumigatus strains YCY2 (KM268716) and DYJ1 (KM268635; Figure 2). Thus, UR01 was assigned as Aspergillus fumigatus UR01.

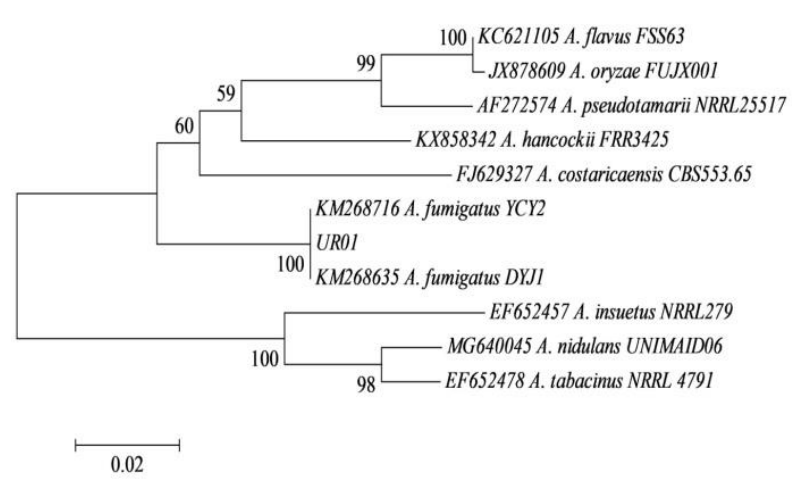

Figure-2. Phylogenetic tree of ITS region from Aspergillus fumigatus UR01 and other fungi were constructed by using the neighbor-joining method (MEGA4).

Percentages of bootstrap values are showed at all branches. The scale bar represents to 0.02 substitutions per nucleotide.

Optimisation of conditions for xylanase production A. fumigatus spores were cultured in a minimal medium supplemented with $2 \%(\mathrm{w} / \mathrm{v})$ xylan and incubated at $45^{\circ} \mathrm{C}$ for 10 days. Xylanase activity was measured in culture filtrates at various temperatures $\left(30^{\circ} \mathrm{C}-75^{\circ} \mathrm{C}\right)$ and $\mathrm{pH}(3-6)$ conditions; a $\mathrm{pH}$ range of 3-6 was used because xylan could not be dissolved in acidic $(\mathrm{pH}<3)$ or alkaline $(\mathrm{pH}>6)$ buffers. Xylanase activity was the highest at $55^{\circ} \mathrm{C}$ (Figure 3 ) and $\mathrm{pH} 5.0$ (Figure 4). According to other studies, the optimum $\mathrm{pH}$ and temperature for $A$. fumigatus growth ranged 3.0-6.0 and $55^{\circ} \mathrm{C}-60^{\circ} \mathrm{C}$, respectively (Ang et al., 2013; Gomes et al., 2016).

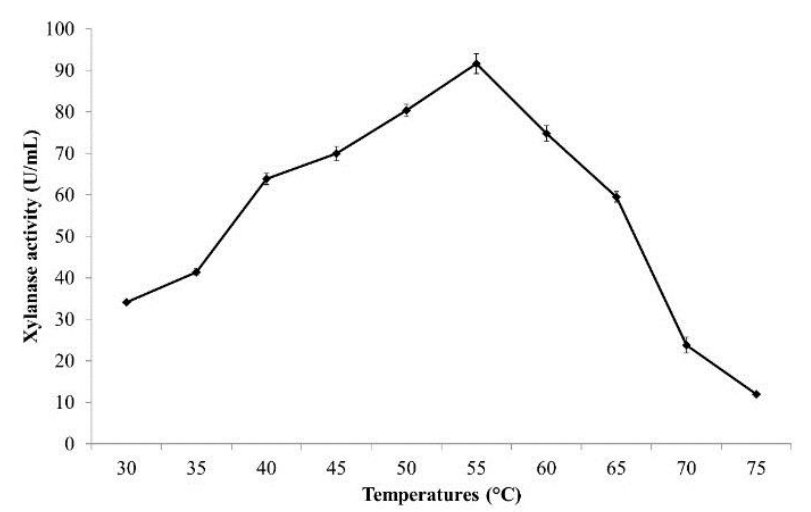

Figure-3. Effect of temperatures on xylanase activity from $A$. fumigatus UR01

In addition, the cellulase activity in culture filtrate of A. fumigatus UR01 was very low (data not shown). It implied that the degradation of rice straw was mainly affected by xylanase. 


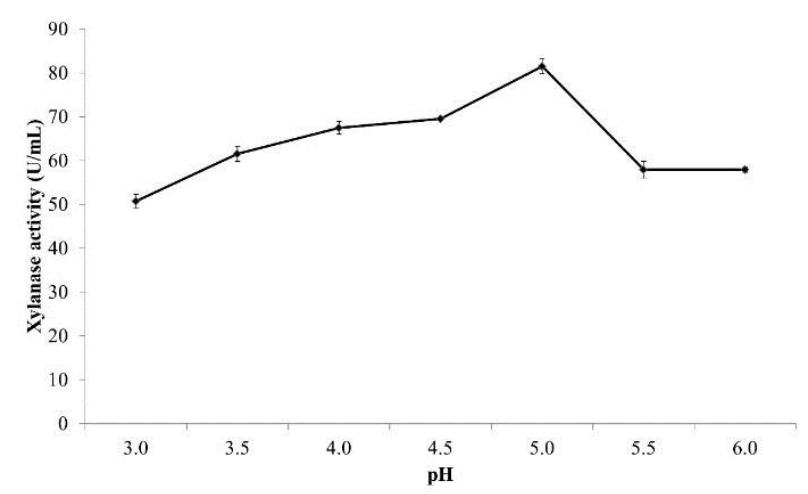

Figure-4. Effect of pH on xylanase activity from $A$. fumigatus UR01

\section{Xylanase stability}

Culture filtrates were incubated at $50^{\circ} \mathrm{C}, 60^{\circ} \mathrm{C}$ or $70^{\circ} \mathrm{C}$, and xylanase activity was determined every 2 days. The residual enzyme activity was $45.26 \%$ when incubated at $50^{\circ} \mathrm{C}$ for 6 days and become almost $0 \%$ by 20 days. At $60^{\circ} \mathrm{C}$ and $70^{\circ} \mathrm{C}$, the enzyme activity was lost after 2 days of incubation (Figure 5). According to other studies, the residual enzyme activity at $60^{\circ} \mathrm{C}-70^{\circ} \mathrm{C}$ was $40 \%-53 \%$ after incubation for 60 min (Bajaj and Abbass, 2011).

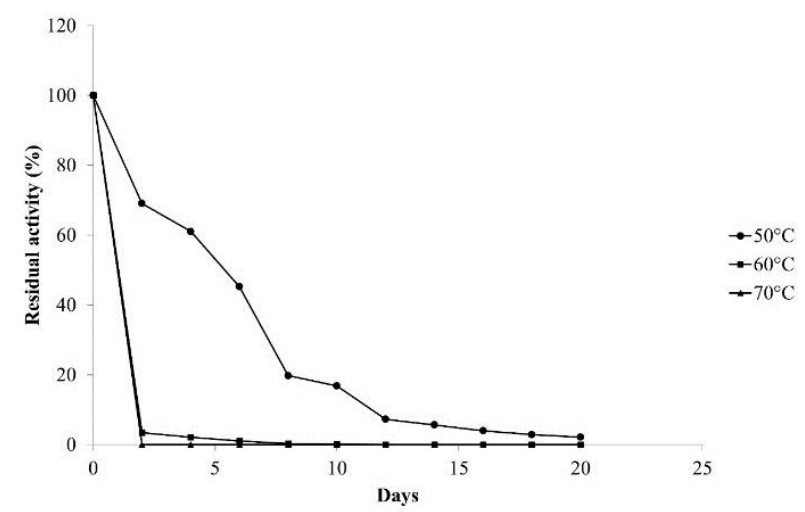

Figure-5. Residual activity of crude enzyme when were incubated at 50,60 and $70{ }^{\circ} \mathrm{C}$

\section{Solid state fermentation}

Agricultural wastes (husk, rice bran, nutshell, rice straw, sawdust, coconut residue, coir bagasse, corn husk and corn cob) were used as substrates for fungal culture. However, A. fumigatus UR01 did not grow on bagasse, corn husk, coir or corn cob (data not shown). The highest xylanase activity $(161.20 \pm 3.34 \mathrm{U} / \mathrm{g}$ of dried substrate) was detected when the fungus was grown on rice straw (Figure 6).
Rice straw is a suitable substrate for xylanase production by many fungi. For instance, Schizophyllum commune ARC-11 showed high xylanase activity for the solid state fermentation of rice straw (Gautam et al., 2018). However, the substrate size affected enzyme production such that the enzyme activity was higher for smaller particle sizes than for larger sizes (Ang et al., 2013).

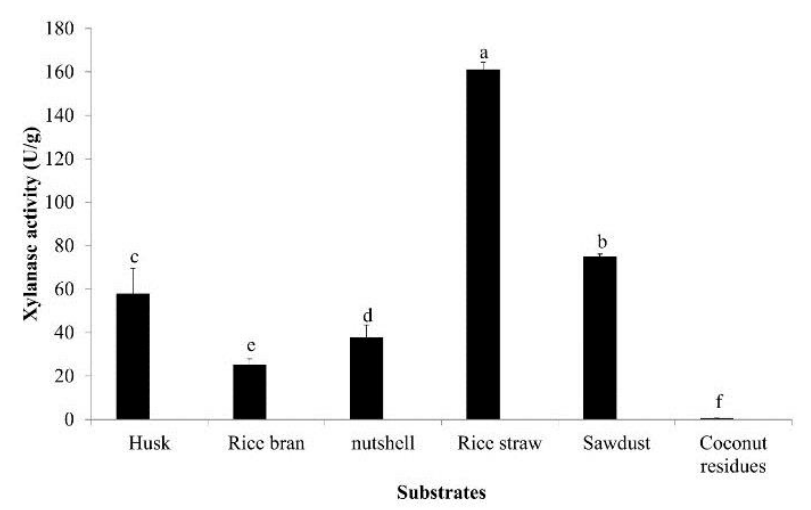

Figure-6. Production of xylanase by $A$. fumigatus UR01 by using various agricultural wastes as carbon sources

\section{Rice straw degradation}

Culture filtrate of $A$. fumigatus UR01 grown on rice straw was added to rice straw. After incubation, the sugars produced via rice straw degradation were determined. The experiment was performed at $30^{\circ} \mathrm{C}$ to simulate the average temperature of tropical countries. The highest proportion of reducing sugars (19.67 $\pm 0.12 \mathrm{mg} / \mathrm{g}$ of dried substrate) was achieved after incubation for $18 \mathrm{~h}$ (Figure 7).

The crude enzyme produced by A. fumigatus contains other enzymes. Cellulases and xylanases are the essential enzymes for sugar production from rice straw. However, A. fumigatus UR01 showed high xylanase activity but low cellulase activity, as described above. Thus, A. fumigatus xylanase plays an important role in sugar production from rice straw.

In a previous study, xylanase was added to rice straw to improve the digestibility of ruminant in livestock feed (Phakachoed et al., 2012). In addition, supplementation of a commercial enzyme with $A$. awamori xylanase could enhance sugar production from rice straw (Choudhary et al., 2014). 


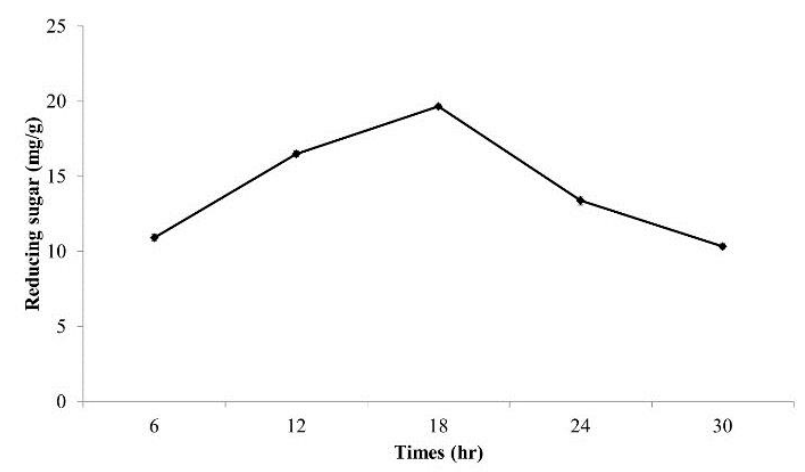

Figure-7. Reducing sugar concentration after crude enzyme incubated with rice straw at room temperature for various time

\section{Conclusion}

The optimal conditions for xylanase production by $A$. fumigatus UR01 were $55^{\circ} \mathrm{C}$ and $\mathrm{pH}$ 5.0. The crude enzyme produced the highest levels of reducing sugar from rice straw when incubated at $30^{\circ} \mathrm{C}$ for 18 hours. These results indicate that xylanase produced by $A$. fumigatus UR01 can be used in many industrial applications such as feed and bioethanol production. Rice straw can be pretreated with xylanase to improve the nutrient content of livestock feed. Moreover, rice straw can be used as a substrate for generating sugars to increase the efficiency of bioethanol production. Finally, rice straw is the most suitable substrate for xylanase production. This substrate is a common and cheap agricultural waste, and its use can reduce the costs of xylanase production.

\section{Acknowledgement}

Authors acknowledge the financial support by Department of Microbiology, Faculty of Science, Silpakorn University, Thailand.

Disclaimer: None.

Conflict of Interest: None.

Source of Funding: This study was funded by Department of Microbiology, Faculty of Science, Silpakorn University, Thailand.

\section{References}

Ang SK, Shaza EM, Adibah Y, Suraini AA and Madihah MS, 2013. Production of cellulases and xylanase by Aspergillus fumigatus SK1 using untreated oil palm trunk through solid state fermentation. Process Biochem. 48: 1293-1302.

Bajaj BK and Abbass M, 2011. Studies on an alkalithermostable xylanase from Aspergillus fumigatus MA28. 3 Biotech. 1: 161-171.

Choudhary J, Saritha M, Nain L and Arora A, 2014. Enhanced Saccharification of Steam-Pretreated Rice Straw by Commercial Cellulases Supplemented with Xylanase. J. Bioprocess. Biotech. 4(7): 188-193.

Chukeatirote E, Sajeewa SN, Maharachchikumbura SSN, Wongkham S, Sysouphanthong P, Phookamsak R and Hyde KD, 2012. Cloning and sequence analysis of the cellobiohydrolase I genes from some basidiomycetes. Mycobiol. 40(2): 107-110.

Gautam A, Kumar A, Bharti AK and Dutt D, 2018. Rice straw fermentation by Schizophyllum commune ARC-11 to produce high level of xylanase for its application in pre-bleaching. J. Genet. Eng. Biotechnol. 16: 693-701.

Gomes AFS, Santos BSL, Fransciscon EG and Baffi MA, 2016. Substract and temperature effect on xylanase production by Aspergillus fumigatus using low cost agricultural wastes. Biosci. J. 32(4): 915-921.

Jayanegara A, Ayinda RSK and Laconi EB, 2017. Urea treatment of rice straw at elevated temperature and pressure: Effects on fiber content, rumen fermentation and digestibility. J. Indonesian Trop. Anim. Agric. 42(2): 81-87.

Khan NA, Hussain S, Ahmad N, Alam S, Bezabhi M, Hendriks WH, Yu P and Cone JW, 2015. Improving the feeding value of straws with Pleurotus ostreatus. Anim. Prod. Sci. 55: 241245.

Maheshwari R, Bharadwaj G and Bhat MK, 2000. Thermophilic Fungi: Their Physiology and Enzymes. Microbiol. Mol. Biol. Rev. 64(3): 461488.

Makhuvelea R, Ncubea I, Rensburga ELJ and Grange DC, 2017. Isolation of fungi from dung of wild herbivores for application in bioethanol production. Braz. J. Microbiol. 48: 648-655.

Miller LG, 1972. Use of dinitrosalicylic acid reagent for determination of reducing sugar. Anal. Chem. 31: 426-429.

Phakachoed N, Lounglawan P and Suksombat W, 2012. Effects of xylanase supplementation on ruminal digestibility in fistulated non-lactating dairy cows fed rice straw. Livestock Sci. 149: 
104-108.

Sheikh GG, Ganai AM, Reshib PA, Bilal S and Mir S, 2018. Improved paddy straw as ruminant feed: A Review. JOJ Sci. 1(1): 1-8.

Sindhu R, Binod P, Janu KU, Sukumaran RK and Pandey A, 2012. Organoslovent pretreatment and enzymatic hydrolysis of rice straw for the production of bioethanol. World J. Microbiol. Biotechnol. 28: 473-483.

Thammiah V, Samanta AK, Senani S and Sridhar M, 2017. Scope of exogenous enzymes in enhancing ruminant productivity. J. Adv. Vet. Anim. Res. 5(2): 137-142.

Thiagarajan S, Jeya M and Gunasekaran P, 2005. Improvement of xylanase production in solid state fermentation by alkali-tolerant Aspergillus fumigatus MKU1 using a fractional design. Indian J. Exp. Biol. 43: 887-891.

\section{Contribution of Authors}

Singhajutha S: Conducted laboratory experiments and literature review

Bangyeekhun E: Helped in experimental design and manuscript write up

Romruen U: Designed the study, conducted laboratory work and wrote manuscript 